\title{
Lymphoepithelioma-like Carcinoma of the Breast: A Case Report and Review of the Literature
}

\author{
Betul B. KUCUKZEYBEK ${ }^{1}$, Hakan POSTACI', Alp OZGUZER ${ }^{1}$, Savas YAKAN², Ali G. DENECLI ${ }^{2}$ \\ ${ }^{1}$ Izmir Bozyaka Training and Research Hospital, Department of Pathology \\ ${ }^{2}$ Izmir Bozyaka Training and Research Hospital, Department of General Surgery, Izmir, TURKEY
}

\begin{abstract}
Lymphoepithelioma-like carcinoma (LELC) is an undifferantiated carcinoma, which occurs in the organs that exclude nasopharynx, has the same morphologic features with nasofarengeal lymphoepithelioma. LELC has been described in several organs however it is rarely seen in the breast. Due to the undifferentiated appearance of neoplastic cells and the presence of prominent lymphocytic infiltrate, LELC can wrongly be diagnosed as lymphoma and medullary carcinoma. In this case present the LELC of the breast in a 58 year-old woman with clinical, histological and immunohistochemical features with differential diagnosis. It is discussed with the relevant literature.
\end{abstract}

Key words: Breast, Lymphoepithelyoma-like carcinoma, Differential diagnosis

\section{ÖZET}

\section{Memenin Lenfoepitelyama Benzeri Karsinomu: Olgu Sunumu ve Literatürün Gözden Geçirilmesi}

Lenfoepitelyoma benzeri karsinom (LEBK), nazofarengeal lenfoepitelyoma ile aynı morfolojik özelliklere sahip, nazofarinks dışında diğer organlarda meydana gelen undiferansiye karsinomdur. LEBK'lar birçok organda tanımlanmış olup memede oldukça nadir görülmektedir. Belirgin lenfoid infiltrat varlı̆̆ı ve tümöral hücrelerin undiferansiye görünümü nedeniyle LEBK, Ienfoma ve medüller karsinom ile karıştırlabilir. Burada 58 yaşında memenin LEBK tanısı alan olgunun klinik, histolojik ve immunohistokimyasal özellikleri literatürler eşliğinde tartışılarak sunuldu.

Anahtar Kelimeler: Meme, Lenfoepitelyoma benzeri karsinom, Ayıııı tanı 


\section{INTRODUCTION}

Lymphoepithelioma, which was first described in the nasopharynx by Regaud and Reverchon, and Schminke in 1921, is an undifferentiated carcinoma with prominent lymphoid infiltration. ${ }^{1}$ Lymphoepithelioma-like carcinomas (LELCs) are tumors with the same morphological features as undifferentiated nasopharyngeal carcinomas. ${ }^{2}$ LELCs have been reported in the salivary glands, stomach, lungs, and thymus, and less often in the skin, uterine cervix, and bladder. ${ }^{3}$ Breast LELC was first reported by Kumar et al. in 1994. ${ }^{4}$ Although it was shown that there is a relationship between LELCs in the stomach, lungs, and salivary glands, and Epstein-Barr virus (EBV), such a relationship has not yet been observed in other organs, including the breast..$^{3.5-7}$

A search of the English-language literature showed that there are only 15 cases with LELC of breast reported. Herein we present a patient diagnosed with breast LELC, the case's clinical, histological, and immunohistochemical features, and a discussion based on a review of the literature.

\section{CASE}

A 58-year-old female patient with a right breast mass was admitted to the general surgery department of our hospital. Mammography showed a $7 \mathrm{x}$ $7 \mathrm{~cm}$ mass in the inner-middle quadrant of the right breast; differential diagnosis could not be performed due to the potential for abscess or malignancy. The patient, whose mother and sister have a history of breast carcinoma, underwent incisional biopsy.

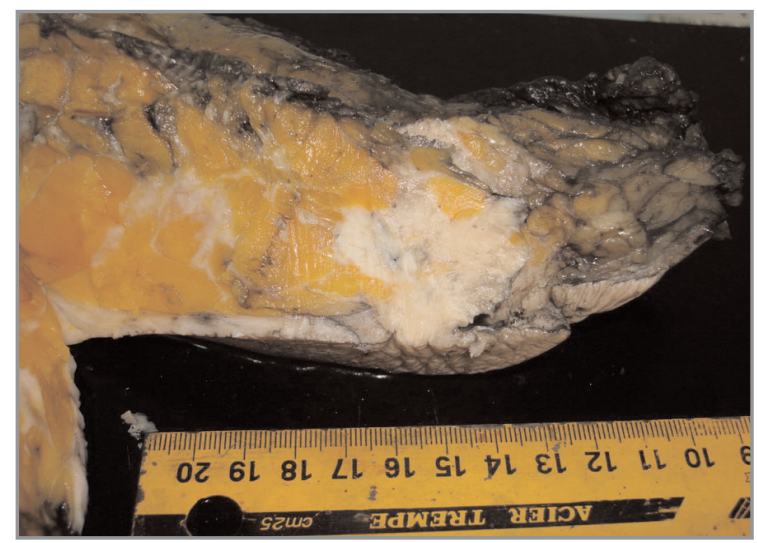

Figure 1. Macroscopic view of the tumor
The incisional biopsy pathology report indicated a breast carcinoma and approximately 1 month later the patient underwent modified right radical mastectomy and axillary dissection; the material was sent to the pathology department.

In the macroscopic examination of the material had a white purulent fluid discharge and an infiltrating $3 \times 3 \times 2.5 \mathrm{~cm}$ tumor located in the medium inner quadrant of the right breast (Figure 1). Histopathological examination at low magnification showed that there were nodular areas formed by lymphoid cells. In the infiltrating tumor lymphocytes, which were predominant in nodular areas, and a small number of plasma cells appeared mixed with the tumor cells. Tumor cells were large and vesicular, with round-oval nuclei, distinct nucleoli, and narrow cytoplasm. Their cytoplasmic borders were not clear. Tumor cells were scattered, either alone or in cords, or were like small islands located in the ground, which was lymphocyte-predominant (Figures 2-4). Mitosis was 3-5/10 high-power fields and necrotic foci were observed. In the non-tumoral breast tissue lobules were infiltrated by lymphoid cells. There was no metastasis in the 24 lymph nodes dissected from the axilla. Immunohistochemical (IHC) examination showed that the tumor cells were cytokeratin 7 (+) (Figure 5), cytokeratin 20 $(-)$, ER (-), PR (-), and Cerb-B2 (-). In the lymphoid cells, which were mixed with tumor cells, mostly CD3 (+) positivity and some CD20 (+) positivity was observed. There was a moderate degree of fibrotic tissue proliferation in the nearby tissues. Ductal or lobular carcinoma in situ was not obser-

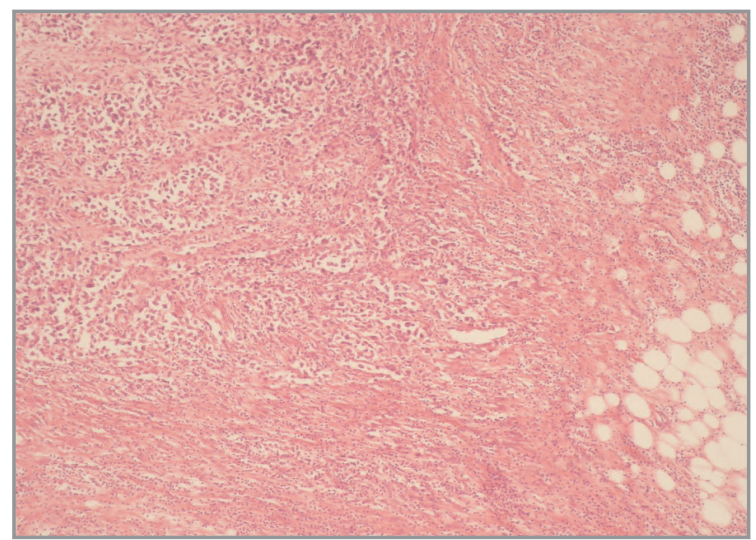

Figure 2. Neoplastic cells of infiltrating marginated tumor in lymphoid rich stroma (HE x 10)

UHOD Number: 2 Volume:21 Year: 2011 


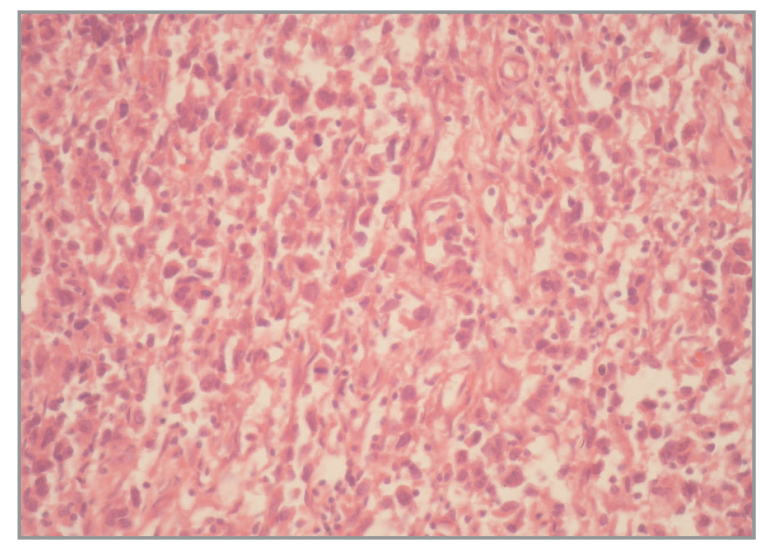

Figure 3. Individually dispersed tumor cells mixed with mononuclear inflammatory cells (HE x 40)

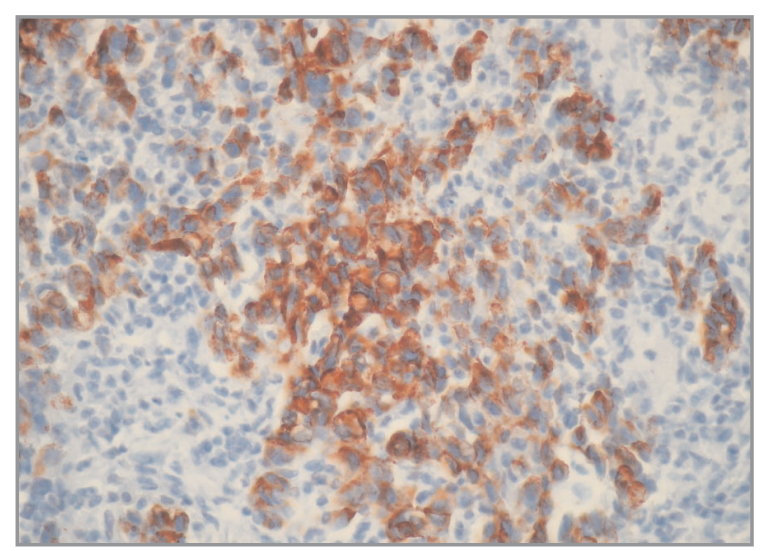

Figure 5. Immunochemically cytokeratin $7(+)$ tumor cells (x40)

ved in a large proportion of the material examined. The patient was diagnosed as LELC of the breast, based on the histologic and immunohistochemical findings. Local recurrence occurred 1.5 years later and the patient received adjuvant chemotherapy. There was no evidence of distant metastasis and the patient was scheduled for palliative chemotherapy.

\section{DISCUSSION}

Lymphoepithelioma is an undifferentiated carcinoma, which was originally described in the nasopharynx..$^{1,8-10}$ LELCs are tumors that occur in all organs, except for the nasopharynx, and they have the same morphological features as nasopharyngeal lymphoepithelioma. ${ }^{9}$ LELCs are characterized by malignant epithelial cells, which are in the form of

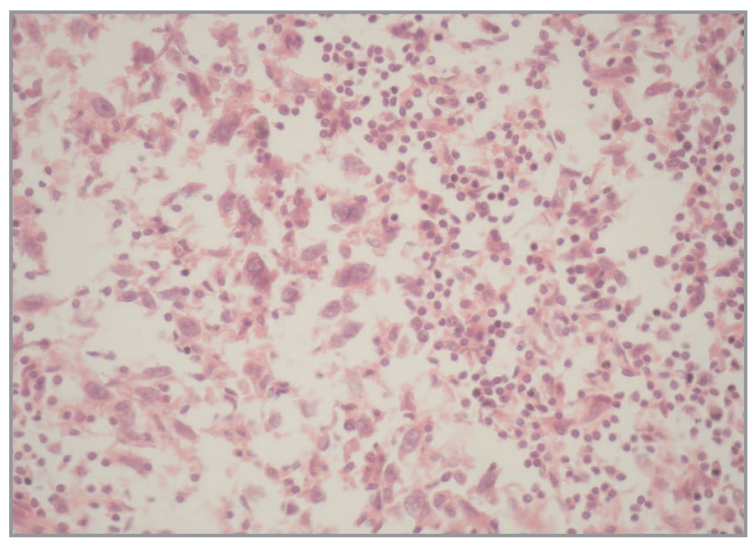

Figure 4. Tumor cells with large nuclei and conspicious nucleoli mixed with lymphoid cells (HE x 40)

islets or cords, or are syncytial in structure or scattered individually. They contain prominent lymphoid stroma. ${ }^{8,10}$

Because medullary carcinoma, atypical medullary carcinoma, and some ductal or lobular carcinomas can have prominent lymphoid stroma, they should be considered in the differential diagnosis of LELCs. ${ }^{2,10}$ In addition, the differential diagnosis of LELC should include non-Hodgkin's lymphoma. Lymphomas have diffuse neoplastic proliferation of lymphoid cells, but do not have an epithelial component; however, sometimes in H\&E-stained sections it can be difficult to differentiate between malignant epithelial cells and mononuclear lymphoid cells. ${ }^{10}$ EMA and cytokeratin stains, which are used for immunohistochemical analysis, are very useful in showing the nature of tumor epithelial cells located between lymphocytes and plasma cells. ${ }^{2,9}$ LELCs that exhibit a syncytial growth pattern in the presence of dense lymphoid cell infiltration are sometimes misdiagnosed as medullary carcinoma. In medullary carcinoma the tumoral margin is typically well circumscribed. Tumor cells are separated from adjacent stroma by a sharp border. The syncytial growth pattern is $>75 \%$ and they are formed by poorly differentiated cells, whose nuclear degrees contain high mitotic rate..$^{9,10}$

In invasive ductal or lobular breast carcinomas the inflammatory infiltrate may sometimes be observed in the stroma; however, the quantity of mononuclear infiltrate is low and not more than that observed in LELCs. Nonetheless, structural growth patterns (tubular, cribriform structures, diffuse sheets), cyto- 
logical features (monomorphic low nuclear grade nuclei, distinct cell borders, intracytoplasmic lumens), and stromal desmoplasia are helpful in differentiating ductal or lobular carcinoma with inflammatory stroma from LELC. ${ }^{10}$ The relationship between LELC and EBV varies by organ. The presence of the EBV genome in LELC was observed in the salivary glands, lungs, stomach, and thymus, whereas the relationship was not observed elsewhere, including the skin and uterine cervix..$^{3,5-7,11}$ In terms of the relationship between EBV and breast LELC, in all previous reports of breast LELC the presence of the EBV genome, which was investigated by various methods, was not noted..$^{1,2,4,10,12-14}$

Regarding immunohistochemical studies on LELC, Kumar et al., Pesterelli et al., and Ilvan et al. reported ER and PR positivity in tumor cells, and Sanati et al. and Kulka et al. observed only ER positivity, whereas Dadmanesh et al. reported that in all but 1 of their cases ER and PR positivity was not noted. Again, Cerb-B2 positivity was observed only by Kurose et al., while the other reported cases were Cerb-B2 negative..$^{2,4,10,13-5}$ In a study of 6 cases by Dadmanesh et al. low molecular weight cytokeratin and EMA were positive, and high molecular weight cytokeratin and actin were negative in all the cases. ${ }^{10}$ In the presented case immunohistochemical examination results for ER, PR, Cerb-B2, CD3, and CD20 were negative, whereas cytokeratin 7 was positive, which is in contrast with the staining pattern of ER, PR, and Cerb-B-2 in most of the previously reported cases.

Despite the lack of long-term follow-up, breast LELC was reported to have a good prognosis..$^{1,2,4,10,12,15}$ Axillary lymph node metastasis occurred in 1 of the 6 cases reported by Dadmanesh et al., and in 1 case reported by Naidoo et al. and Pesterelli et al., whereas in the other reported cases axillary lymph node metastasis was not observed. In our case 24 lymph nodes were dissected and metastases were not observed. Additionally, in our case, only 3 of the 16 other published cases reported axillary lymph node metastases; therefore breast LELC is considered to have a good prognosis. $\mathrm{Ku}-$ mar et al., Cristina et al., Naidoo et al., Dadmanesh et al., and Ilvan et al. reported recurrence-free survival after 3-72 months of follow-up, whereas in 2005 Kurose et al. reported a case with parasternal and lung metastases after 19 months. In the presented case local recurrence occurred after 1.5 years of follow-up and distant metastases were not observed.

LELC, which is a rare carcinoma of the breast, should be considered in the differential diagnosis of breast carcinomas with dense lymphoid cell infiltration and breast lymphomas, and it should be regarded as a specific variant of invasive breast carcinoma.

\section{KAYNAKLAR}

1. Naidoo P, Chetty R. Lymphoepithelioma-like carcinoma of the breast with associated sclerosing lymphocytic lobulitis. Arch Pathol Lab Med 125: 669-72, 2001.

2. Ilvan S, Celik V, Akyildiz EU, et al. Lymphoepitheliomalike carcinoma of the breast: is it a distinct entity? Clinicopathological evaluation of two cases and review of the literature. The Breast 13: 522-526, 2004.

3. lezzoni JC, Gaffey MJ, Weiss LM. The role of EpsteinBarr virus in lymphoepithelioma-like carcinomas. Am J Clin Pathol 103: 308-15, 1995.

4. Kumar S, Kumar D. Lymphoepithelioma-like carcinoma of the breast. Mod Pathol 7: 129-31, 1994.

5. Chen F, Yan J, Lai W, et al. Epstein-Barr virus-associated nonsmall cell lung carcinoma. Undifferentiated "lymphoepithelioma-like" carcinoma as a distinct entity with better prognosis. Cancer 82: 2334-42, 1998.

6. Kuo T, Hsueh C. Lymphoepithelioma-like salivary gland carcinoma in Taiwan: a clinicopathological study of nine cases demonstrating a strong association with Epstein-Barr virus. Histopathology 31: 75-82, 1997.

7. Min KW, Holmquist S, Peiper SC, O'Leary TJ. Poorly differentiated adenocarcinoma with lymphoid stroma (lymphoepithelioma-like carcinomas) of the stomach. Report of three cases with Epstein-Barr virus genome demonstrated by the polymerase chain reaction. Am J Clin Pathol 96: 219-27, 1991.

8. Shanmugaratnam K, Chan SH, de-The' G, et al. Histopathology of nasopharyngeal carcinoma. Correlations with epidemiology, survival rates and other biological characteristics. Cancer 44: 1029-44, 1979

9. Kurose A, Ichinohasama R, Kanno H, et al. Lymphoepithelioma-like carcinoma of the breast. Report of a case with the first electron microscopic study and review of the literature. Virchows Arch 447: 653-659, 2005.

10. Dadmanesh F, Peterse JL, Sapino A, et al. Lymphoepithelioma-like carcinoma of the breast: lack of evidence of Epstein-Barr virus infection. Histopathology 38: 54-61, 2001. 
11. Martorell MA, Julian JM, Calabuig C, et al. Lymphoepithelioma-like carcinoma of the uterine cervix. A clinicopathologic study of 4 cases not associated with Epstein-Barr virus, human papillomavirus, or simian virus 40. Arch Pathol Lab Med 126: 1501-1505, 2002.

12. Cristina S, Boldorini R, Brustia F, Monga G. Lymphoepithelioma-like carcinoma of the breast: an unusual pattern of infiltrating lobular carcinoma. Virchows Arch 437: 198-202, 2000.

13. Pestereli HE, Erdogan O, Kaya R, Karaveli FS. Lymphoepithelioma-like carcinoma of the breast. A newly recognized subtype of lobular carcinoma. APMIS 110: 447-450, 2002.

14. Kulka J, Kovalszky I, Svastics E, et al. Lymphoepithelioma-like carcinoma of the breast: not Epstein-Barr virus-, but human papilloma virus-positive. Hum Pathol 39: 298-301, 2008.

15. Sanati S, Ayala A, Middleton L. Lymphoepitheliomalike carcinoma of the breast: Report of a case mimicking lymphoma. Ann Diag Pathol 8: 309-315, 2004.

\section{Yazışma Adresi}

Dr. Betül Bolat KÜÇÜKZEYBEK

Van Devlet Hastanesi Patoloji Laboratuarı

65100 Merkez

Van / TURKEY

Tel: (+90.432) 2157600

e,mail: bbkzeybek@yahoo.com 